\title{
Fisheries innovative data collection strategy: the case of self sampling in artisanal fisheries of Bonny, Nigeria
}

\author{
Parcy O. ABOHWEYERE
}

\author{
Nigerian Institute For Oceanography \& Marine Research Wilmot Point Road, Bar-Beach, Victoria Island, \\ Lagos, Nigeria. \\ E-mail: ochukoparcy@yahoo.com,Tel: +234-8023006855
}

\begin{abstract}
Fisheries data collection by self sampling strategy in an artisanal fishery in the Niger Delta area (Bonny) was examined. Forty (40) fishermen from eight (8) fishing communities were trained on sampling and recording of their catch. The fishermen continuously self sampled their catch for a total of 269 days. Fifty-four (54) fish species including commercially important fish species in the Nigerian Fisheries Sector were recorded from all the communities by the fishermen. Data collected provided baseline information on Bonny area fisheries, which gave salient performance indicators of the fisheries such as the catch per unit effort (CPUE), species size ranges and frequency of exploitation of fishing grounds. The data also revealed the most abundant sizes of various commercially important species. The total number of continuous self sampling days was approximately 7 times more than that spent by fishery personnel thus indicating the inherent advantage in self sampling, which is the opportunity for more sampling and invariably more data. The cost-effective requirement of data collection strategy was achieved by the fishermen self sampling their catch thereby reducing fisheries personnel cost. The importance of this innovative strategy for developing countries such as Nigeria was discussed.
\end{abstract}

(C) 2011 International Formulae Group. All rights reserved.

Keywords: Artisanal Fisheries; Data Collection Strategy; Innovative; Self-Sampling.

\section{INTRODUCTION}

Strategies for the design of data collection programmes vary between fisheries. Each fishery requires its own strategy with elements of complete enumeration and sampling. Sampling strategies are often punctuated by complete enumeration from time to time to re-evaluate baseline data (FAO, 1998). Flexibility and adoption of alternative approaches form a key component of any strategy, whether it is designed for assessment of fish stocks, the evaluation of markets or the assessment of community dependence on fisheries (Caddy and Bazigos, 1985).

Fisheries data collection strategies have requirements that need to be met ranging from evaluation of existing data sets in relation to the objectives of the programme, description of the operating characteristics of the sector, also known as the census or frame survey (Asia-Pacific Fishery Commission, 1997). A generic design for data collection is neither appropriate nor achievable, context specific system tailored to meet local needs and capacity is essential (Halls, 2005). The 
decision on the approach to be taken is dependent on whether, complete enumeration or sampling, including cost-benefit and costeffectiveness analysis and an evaluation of operational considerations (institutional, financial and human resources) is required. (Cochran, 1977; Date, 1985; Arte, 1988; Eurostat, 1997).

Evaluation of the precision of alternative data collection methods are relatively common. Fewer studies however, have estimated the cost required to achieve a given precision. In the fisheries management context, the benefit of data collection should not be measured in terms of the precision but in relation to the achievement of management objectives (Bentley and Stokes, 2009). Data collection system or programmes must be designed to support the diverse needs of a range of potential stakeholders, tailored according to their objectives, capacity and available resources (Halls, 2005). Participation by other stakeholders, establishment of a continuing feedback mechanism between data sources and data users to ensure that data types, quantity, quality and origin should be consistent with the requirement for determination of the performance indicator in question.

Indicators of fishery status are usually constructed from a series of data types and variables which are interpreted in relation to agreed reference points corresponding to intended objectives (FAO, 1998). A critical concern for data collection is consistency. Catch and effort data are critical to construct the most important indicators in most fisheries. Estimated catch per unit effort and effective effort on a regular basis is the most commonly used method to describe trends in fisheries (FAO, 2011).

Baseline information generation on the fisheries in the Bonny area which will help to properly assess and mitigate potential impact of a development process termed "channel deepening project" by Nigeria Liquefied Natural Gas (NLNG) limited, informed the development of strategies for fisheries data collection in the study area. The research project collected and presented information on the role of fisheries in the socio-economic system of the Bonny estuary of the Niger Delta and its environ. This will serve as a baseline for future comparison and also for the intended environmental, social and health impact assessment. This paper examined a self sampling strategy employed in the collection of fisheries information in the artisanal fisheries in the Bonny area of Nigeria.

\section{MATERIALS AND METHODS}

\section{Study area}

The Bonny Channel Deepening Baseline Fisheries studies in the Niger Delta area covered communities on the Bonny, New Calabar, Sombriero and Andoni Rivers Systems in Rivers State, Nigeria. The communities were Amariari, Elem -Ifoko, Fakpa, Ferupakama, Oke-Eri, Oruma, Oyorokoto and Sodieyenkiri.

\section{Selection criteria for communities and fishermen}

The community and fishermen selections were done on the basis of predetermined criteria which were as follows:

Community - intensity of fishing activities, population involved in fishing, gear type used and quantity, volume and size of fished landed.

Fishermen - literacy, membership of economic / cooperative group, level of fishing activity, gear type, craft type, quantity and size of catch.

\section{Training and equipping of fishermen data collectors}

The selected fishermen were trained by the scientists in basic record taking with demonstrations on how the measurements were to be made (Fig. 1). The information they recorded were - date of fishing, name of fish, weight of fish per species, total weight of 
catch, length frequency of fish sample, total price of fish per species, total price of catch, place of fishing, time of setting out, time of return, number of crew on board, type of canoe, type of engine, HP of engine. After the training, each of the fishermen were given materials for executing the task, and these were; weighing balance, measuring board, Nigerian Institute for Oceanography and Marine Research (NIOMR) fish chart, hard cover note book, biros, pencils, eraser and sharpener. The fishermen were also given small stipend as incentives.

\section{Fish landing data collection and analysis}

There were five (5) surveys conducted by the research team. A day was devoted to each community per survey in which all boats landed were sampled. The selected fishermen self sampled their own catches in the intervals between each of the research surveys and recorded the agreed data types. Data were extracted from the fishermen's logbooks and filled in $\log$ forms. Data so prepared were entered into a database in Microsoft Excel. The data were analyzed for species encountered, catch per unit of effort (CPUE), species size ranges, most abundant size, fishing ground exploited and frequency.

\section{RESULTS}

A total of forty (40) fishermen comprising of five in each of the eight communities self sampled their catch for a total of 269 days, from $10^{\text {th }}$ October 2004 to $7^{\text {th }}$ July 2005.

\section{Fish landings}

The total number of fish species recorded by fishermen in all the communities was 54. Included among these were the commercially important species in the Nigerian Fishery Sector, such as the croakers (Pseudotolithus elongatus, Pseudotolithus typus, Pseudotolithus senegalensis) catfish (Arius gigas), caranx (Caranx hippos), grunter (Pomadasys jubelini) and sole (Cynoglossus senegalensis). Others were shinynose (Polydactylus quadrifilis), red snapper (Lutjanus agennes), threadfin (Galeodies decadactylus), barracuda (Sphyraena guachancho), spade fish (Drepane africana), bonga (Ethmalosa fimbriata), sardine (Sardinella maderensis) and mackerel (Scomberomorus tritor).

\section{CPUE / fishing ground}

Fishermen catch per unit of effort (CPUE) per trip in the different fishing grounds varied. For Andoni Ocean; and Andoni River \& Creeks, the CPUE ranged from 0.09 to $168 \mathrm{~kg}$, averaging $7.96 \mathrm{~kg}$ and 0.16 to 400 averaging $7.27 \mathrm{~kg}$ respectively. Bonny estuary, Bonny Ocean and Bonny River \& Creeks were 0.07 - $433.33 \mathrm{~kg}, 0.1$ $300 \mathrm{~kg}$ and $0.04-114.29 \mathrm{~kg}$ with averages of $8.18,18.97$ and $4.99 \mathrm{~kg}$ respectively. For New Calabar River \& Creeks it was 0.75 - 41.95 $\mathrm{kg}$ with an average of $13.25 \mathrm{~kg}$. While for Sombreiro Ocean and Sombreiro River \& Creeks they were $0.71-40 \mathrm{~kg}$ and $0.28-18$ $\mathrm{kg}$ averaging 6.92 and $4.27 \mathrm{~kg}$ respectively.

\section{Species size ranges and most abundant size}

The size ranges of the various species varied in the different fishing grounds. For instance, croaker Pseudotolithus elongatus varied between $15-54 \mathrm{~cm}$ in samples from Andoni Ocean fishing ground, $18-53 \mathrm{~cm}$ in Bonny Ocean, 9-53 cm in Bonny Estuary, 17$33 \mathrm{~cm}$ in New Calabar River and Creeks, 10$34 \mathrm{~cm}$ in Bonny River and Creeks, and 16-32 $\mathrm{cm}$ in Sombreiro River and Creeks. In general the size ranges in the ocean fishing grounds were higher. Table 1 presents the size ranges for the different fishing grounds. The most abundant sizes of commercially important species encountered comprised mostly of juveniles. The most abundant sizes for Sardinella maderensis, Ethmalosa fimbriata, Ilisha africana, Cynoglossus senegalensis, and Pseudotolithus elongatus were 10, 15, 13, 37 and $32 \mathrm{~cm}$ respectively. For Pomadasys jubelini, Pseudotolithus senegalensis, 
Pseudotolithus typus and Polydactylus quadrifilis were 11, 28, 20 and $13 \mathrm{~cm}$ respectively.

\section{Fishing ground $\&$ frequency of exploitation} The fishing ground exploited by the fishermen from all the communities were categorized into 8 and these were Bonny Ocean, Bonny Estuary, Bonny River \& Creeks, Andoni Ocean, Andoni River \& Creeks, New Calabar River \& Creeks,
Sombreiro Ocean and lastly Sombreiro River $\&$ Creeks. The frequency of exploitation of these fishing grounds indicated the percentage to be 10, 20, 25 and 3 for Bonny Ocean, Bonny Estuary, Bonny River \& Creeks and New Calabar River \& Creeks respectively. While Andoni Ocean, Andoni River \& Creeks, Sombreiro Ocean and Sombreiro River \& Creeks were 23, 9, 5 and $5 \%$ respectively.

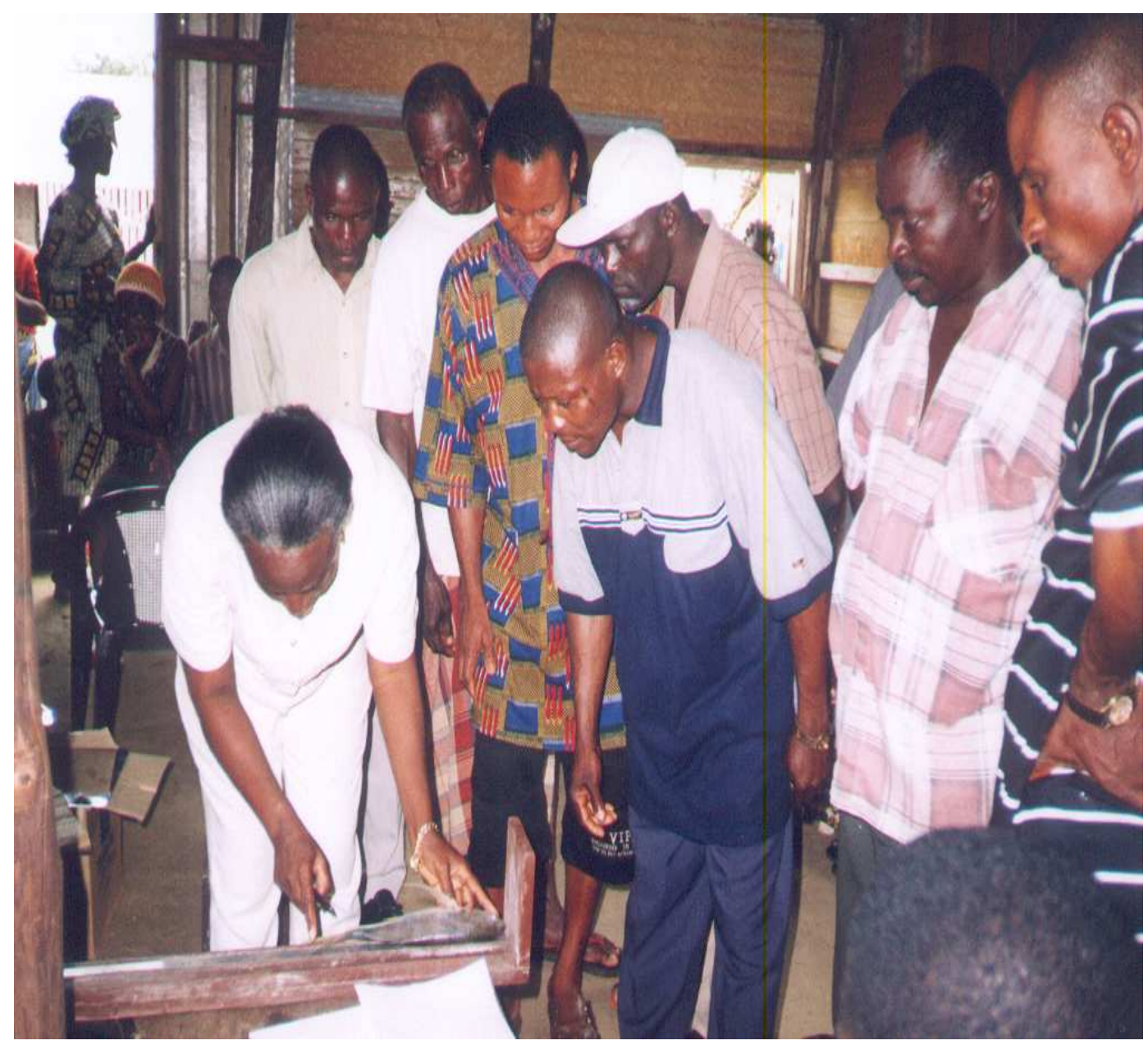

Figure 1: Training session for fishermen data collectors in one of the selected communities 
P. O. ABOHWEYERE. / Int. J. Biol. Chem. Sci. 5(5): 2014-2021, 2011

Table 1: Species size ranges in different fishing ground.

\begin{tabular}{|c|c|c|c|c|c|c|c|c|}
\hline \multirow[t]{2}{*}{ Species } & \multicolumn{8}{|c|}{ Fishing ground } \\
\hline & $\begin{array}{l}\text { Andoni } \\
\text { Ocean }\end{array}$ & $\begin{array}{l}\text { Bonny } \\
\text { Ocean }\end{array}$ & $\begin{array}{c}\text { New Calabar River \& } \\
\text { Creeks }\end{array}$ & $\begin{array}{c}\text { Sombreiro } \\
\text { Ocean }\end{array}$ & $\begin{array}{l}\text { Bonny } \\
\text { Estuary }\end{array}$ & $\begin{array}{c}\text { Bonny } \\
\text { River \& } \\
\text { Creeks }\end{array}$ & $\begin{array}{c}\text { Sombreiro } \\
\text { River \& } \\
\text { Creeks } \\
\end{array}$ & $\begin{array}{l}\text { Andoni River } \\
\text { \& Creeks }\end{array}$ \\
\hline Arius gigas & $22-29$ & $17-64$ & & $14-43$ & $21-46$ & & $15-42$ & - \\
\hline $\begin{array}{l}\text { Pseudotolithus } \\
\text { elongatus }\end{array}$ & $15-54$ & $18-53$ & $17-33$ & - & $9-53$ & $10-34$ & $16-32$ & $15-23$ \\
\hline Pseudotolithus typus & $25-31$ & $26-48$ & - & - & $20-35$ & $12-33$ & $19-27$ & - \\
\hline $\begin{array}{l}\text { Pseudotolithus } \\
\text { senegalensis }\end{array}$ & - & $30-47$ & - & $16-33$ & $18-32$ & - & $16-40$ & - \\
\hline $\begin{array}{l}\text { Polydactylus } \\
\text { quadrifilis }\end{array}$ & $40-44$ & $40-107$ & $29-47$ & - & $12-76$ & $10-30$ & $31-70$ & $18-30$ \\
\hline Pomadasys jubelini & $14-39$ & $12-43$ & $16-27$ & - & $8-57$ & $10-21$ & $12-34$ & $12-21$ \\
\hline Ethmalos a fimbriata & $16-28$ & $15-45$ & - & - & $8-27$ & $11-17$ & $20-30$ & - \\
\hline Sardinella maderensis & $9-25$ & $22-28$ & $5-13$ & - & $3-26$ & $6-24$ & - & $9-16$ \\
\hline Caranx hippos & $23-35$ & $15-26$ & - & - & $6-32$ & $9-9$ & $19-19$ & - \\
\hline $\begin{array}{l}\text { Galeoides } \\
\text { decadactylus }\end{array}$ & $13-27$ & $21-30$ & $11-20$ & - & $9-28$ & $13-13$ & $30-32$ & - \\
\hline $\begin{array}{l}\text { Cynoglossus } \\
\text { senegalensis }\end{array}$ & $9-37$ & $23-34$ & - & - & $11-31$ & $24-24$ & - & - \\
\hline $\begin{array}{l}\text { Sphyraena } \\
\text { guachancho }\end{array}$ & - & - & - & - & $65-71$ & $76-76$ & - & - \\
\hline Scomberomorus tritor & - & $24-51$ & $17-26$ & - & $15-37$ & $14-15$ & - & - \\
\hline Drepane africana & - & $16-21$ & $11-11$ & - & $7-18$ & $7-15$ & - & $15-18$ \\
\hline
\end{tabular}




\section{DISCUSSION}

Self sampled data collected by fishermen in the study area included commercially important fish species in the Nigerian Fisheries Sector. The total number of 269 days of continuous self sampling by the fishermen as against 40 days by the research team showed approximately 7 (6.725) times more sampling than the research team. This revealed the inherent advantage in self sampling when executed properly and the opportunity for more sampling and invariably more data. Self sampling could provide valuable information on the abundance and distribution of commercial species and improve the quality of the data available to scientists and managers (Vandemaele et al., 2011).

Cost effective mechanisms for the collection of data and information in fisheries development and management is conspicuously lacking in most developing countries (Halls, 2005). The fishermen self sampling their catch was cost-effective in this case considering that data collection continued during the intervals between surveys when the research team was not in the field. This feature is one of the important requirements in any strategy for data collection (Cochran, 1977), especially for developing country such as Nigeria. ICES (2007) stated that using scientists to collect information on commercial catches is usually not cost effective and currently there are ongoing efforts worldwide for fishermen to self sample their catches. The involvement of fishers in the assessment process is the ultimate benefit of self sampling programme. According to Volstad et al. (2011), surveys based on self sampling can yield accurate estimates of catch and effort.

The objective of the project which was the provision of baseline information on the fisheries of the Bonny area was achieved as the analysis of the data collected by the fishermen gave salient performance indicators of the fisheries. This is in accordance with FAO (1998) that stated that interpretation of data should give fishery indicators corresponding to intended objectives. It was shown that sizes of the species in the fishing ground in the Oceans were higher than those in the Estuaries, Rivers and Creeks fishing grounds. The croaker species Pseudotolithus elongatus for example, ranged from 15 $54 \mathrm{~cm}$ in catches from the Andoni Ocean fishing ground, $18-53 \mathrm{~cm}$ in the Bonny Ocean fishing ground whereas in catches from the Bonny Estuary, New Calabar River and Creeks, Bonny River and Creeks, and Sombreiro River and Creeks fishing grounds, the sizes were $9-53 \mathrm{~cm}, 17-33 \mathrm{~cm}, 10-34$ $\mathrm{cm}$ and $16-32 \mathrm{~cm}$ respectively. The same trend was observed for the threadfin Galeoides decadactylus and bonga shad Ethmalosa fimbriata. This showed that the Rivers and Creeks could be the breeding and spawning grounds of these fisheries resources with the juveniles of the species being the stage of their life cycles that was most exploited.

There were more catches made from fishing grounds in the ocean compared with fishing grounds in the estuary; rivers and creeks based on the catch per unit effort from these fishing grounds. The highest CPUE from the Bonny Ocean was $300 \mathrm{~kg} /$ trip/day averaging $18.97 \mathrm{~kg} /$ trip/day while from the Bonny River and Creeks fishing ground it was $114.29 \mathrm{~kg} /$ trip/day with the average of 4.99 $\mathrm{kg} /$ trip/day. The examination of the fishermen self sampled data also revealed the most abundant sizes of the various commercially important species. This is in consonance with De Graaf et al. (2011) that stated that sustainable fisheries data and information collection strategies can be found inside the fishery sector through the direct involvement of fishers.

Interpretation of the data provided major fishery performance indicators such as CPUE, species size ranges in the various fishing ground and the most abundant fish sizes. All these are reference points that corresponded to the intended objective which was provision of baseline data / information against which future fishery indicators can be bench marked. According to Halls (2005) self 
sampling generated relevant data and information that is useful for effective formulation and evaluation of policy and development plans.

The data collector's frequency of exploiting the fishing grounds showed that the oceanic fishing grounds were fished less than the estuarine, rivers and creeks fishing grounds. The percentage frequency of the Bonny Ocean being fished for example was only $10 \%$ as against the Bonny River and Creeks with a percentage frequency of $25 \%$. The combination of Bonny Ocean and Bonny Estuary fishing grounds where the actual proposed channel deepening project is domicile however was $30 \%$. This showed the importance of the Channel area to fishing. This information is vital for the project as there is a high possibility of the estuaries being impacted. The generated information provided through self sampling of the fishermen would be a backdrop against which a proper mitigating action can be taken.

In spite of the usefulness of fishermen self sampling their catches, this strategy could be limited by the literacy criteria for fishermen data collectors' selection as this could exclude illiterate fishermen with better experience or skill. This can be solved through adult education program. Another source of bias is the use of different gear types with invariably varied catch efficiency by the fishermen data collectors. Analyzing data on gear basis may resolve this problem. Identification of species with the NIOMR Fish Chart correctly could also be a source of bias. The regular visit of fisheries scientists and validating the identification made by the fishermen resolved this bias.

An artisanal fishery in Nigeria does not have a licensing and registration scheme in place. Therefore arising from this a potential sampling frame to cover all artisanal fishing is the population register. This could be off site registry based vessel operators frame - vessel permits/vessel licenses or on site - site or access point list (points of departure or return for fishing trips).

\section{Conclusion}

The study achieved one of the tenets of data and information gathering strategy criteria of cost effectiveness, by fishermen self-sampling their catch which reduced fisheries personnel cost. This is vital for developing countries where finance could be a constraint to fisheries data and information gathering. Major fishery performance indicators - CPUE, exploited species size ranges and fishing grounds, crucial for rational management were also generated from the fishermen self sampled data.

\section{REFERENCES}

Arte S. 1988. Data Base: Structured Techniques for Design, Performance and Management. John Wiley \& Sons, Inc.: New York; 430p.

Asia-Pacific Fishery Commission. 1997. Status of fishery Statistics in Asia. Report of the first session of the joint Working Party on Fishery Statistics and Economics, Bangkok, Thailand, 19 to 23 August 1997. RAP Publication 1997/43. Bangkok, FAO Regional Office for Asia and the Pacific, 24p

Bentley N, Stokes K. 2009. Moving fisheries from data-poor to data sufficient: Evaluating the cost of management versus the benefits of management. marine and coastal fisheries: Dynamics, Management, and Ecosystem Science, 1: $378-390$.

Caddy J, Bazigos G. 1985. Practical Guidelines for Statistical Monitoring of Fisheries in Manpower Limited Situations. FAO Fish. Tech. Pap. No. 257. Rome, FAO, 86p.

Cochran WG. 1977. Sampling Techniques ( $3^{\text {rd }}$ edn). John Wiley \& Sons, Inc.: London; $428 \mathrm{p}$.

Date CJ. 1985. Introduction to Database System - Sixth Edition. Addison-Wesley. 839p de Graaf GJ, Grainger RJR, Westlund L, Willmann R, Mills D, Kelleher K, Koranteng K. 2011. The Status of Routine Fishery Data Collection in Southeast Asia, Central America, the 
South Pacific and West Africa with special Reference to Small-Scale Fisheries. ICES Journal of Marine Science, 68(8): 1743-1750.

Eurostat. 1997. New Techniques and Technologies for Statistics IIProceedings of the Second Bonn Seminar, IOS Press. 288p.

FAO. 1998. Guidelines for the Routine Collection of Capture Fishery Data. Prepared at the FAO / DANIDA Expert Consultation Bangkok, Thailand, 18-30 May, 1998. FAO, Fisheries Technical Paper 38, 113p.

FAO. 2011. Strategy for Improving Information on Status and Trends of Capture Fisheries - Website. Southeast Asia. FI Institutional Website. In FAO Fisheries and Aquaculture Department (online) Rome. http://www.fao.org/ fishery/topic/16643/en.
Halls AS. 2005. Fisheries Data Collection and Sharing Mechanisms for Co-Management (R8285): Final Technical Report for the Department for International Development MRAG Ltd, London, 31p

ICES. 2007. Report on the Workshop on Using Fishers to Sample Catches, (WKUFS), 5-6 June 2007, Bergen, Norway. ICES CM 2007 / ACFM: 24. $45 \mathrm{p}$

Vandemaele S, Torreele E, Leir H. 2011. Self Sampling: A Step in the Right Direction? Oostende, 11 February 2011.

Volstad JH, Korsbrehhe K, Nedreaas KH, Nilsen M, Nilsson GN, Pennington M, Subbery S, Wienerroither R. 2011. Probability based survey using self sampling to estimate catch and effort in Norway's Coastal Tourist Fishery. ICES Journal of Marine Science, 68: 17851791. 